\title{
Tree mortality, recruitment and growth in a bamboo dominated forest fragment in southwestern Amazonia, Brazil
}

\author{
Herison Medeiros ${ }^{1}$, Wendeson Castro ${ }^{2,4}$, Cleber Ibraim Salimon ${ }^{3}$, Izaias Brasil da Silva ${ }^{3}$ \& Marcos Silveira ${ }^{3}$ \\ ${ }^{1}$ Programa de Pós-graduação em Botânica, Instituto de Pesquisas Jardim Botânico do \\ Rio de Janeiro - JBRJ, Rua Pacheco Leão, 915, CEP 22460-030, Rio de Janeiro, RJ, Brasil \\ ${ }^{2}$ Programa de Pós-graduação Ecologia e Manejo de Recursos Naturais, Universidade Federal do \\ Acre-UFAC, BR 364, Km 4, Distrito Industrial, CEP 69915-900, Rio Branco, AC, Brasil \\ ${ }^{3}$ Centro de Ciências Biológicas e da Natureza, Universidade Federal do Acre-UFAC, \\ BR 364, Km 4, Distrito Industrial, CEP 69915-900, Rio Branco, AC, Brasil \\ ${ }^{4}$ Corresponding author: Wendeson Castro, e-mail: wendesoncastro@gmail.com
}

MEDEIROS, H., CASTRO, W., SALIMON, C.I., SILVA, I.B. \& SILVEIRA, M. Tree mortality, recruitment and growth in a bamboo dominated forest fragment in southwestern Amazonia, Brazil. Biota Neotrop. 13(2): http://www.biotaneotropica.org.br/v13n2/en/abstract?article+bn00613022013

\begin{abstract}
Forest fragmentation affects the structure and dynamics of plant communities, leading to biodiversity loss in forest remnants. In this paper we show that in a bamboo (Guadua weberbaueri Pilger) dominated forest fragment in southwestern Amazonia edge effect may be confounded by bamboo effect, which also occur inside the forest. We measured growth, mortality and, recruitment rate of trees with $\mathrm{DBH} \geq 10 \mathrm{~cm}$, in a fragment of bamboo dominated open forest in southwestern Amazonia, state of Acre, Brazil, in 15 plots at the forest edge and 15 plots inside the forest fragment, $500 \mathrm{~m}$ away from the border. Time interval between censuses was 1.8 years. The average diameter growth rate differed significantly between edge $\left(3.82 \pm 0.10 \mathrm{~mm} \mathrm{a}^{-1}\right)$ and interior $\left(2.39 \pm 0.18 \mathrm{~mm} \mathrm{a}^{-1}\right)$; but there were no differences in annual mortality rate (edge $=3.8 \pm 2.5 \% \mathrm{a}^{-1} \mathrm{CV}=65.7 \%$; interior $=3.6 \pm 2.6 \% \mathrm{a}^{-1} \mathrm{CV}=72.2 \%$ ) or in annual recruitment rate (edge $=7.1 \pm 3.2 \% \mathrm{a}^{-1} \mathrm{CV}=45 \%$; interior $=8.9 \pm 7.9 \% \mathrm{a}^{-1} \mathrm{CV}=88.7 \%$ ). Diameter growth rate, particularly of pioneer and fast-growing trees, is favored by the environmental conditions of the edge, where bamboo abundance is higher. However, the absence of an edge effect on mortality and recruitment could be due to the particular dynamics of bamboo patches, which could be mimicking forest edges and therefore masking possible edge effect in this fragment. We speculate that the mortality and recruitment patterns in fragmented forests of southwestern Amazonia is different from other areas in Amazonia and that bamboo is one of the key controllers of successional processes in these fragments. Keywords: forest fragmentation, edge effect, open forest with bamboo, plant communities, forest succession, tropical forest dynamic.
\end{abstract}

MEDEIROS, H., CASTRO, W., SALIMON, C.I., SILVA, I.B. \& SILVEIRA, M. Mortalidade, recrutamento e crescimento arbóreo em um fragmento florestal dominado por bambu no sudoeste da Amazônia, Brasil. Biota Neotrop. 13(2): http://www.biotaneotropica.org.br/v13n2/pt/abstract?article+bn00613022013

Resumo: A fragmentação florestal afeta a estrutura e dinâmica das comunidades vegetais, levando a perda da biodiversidade nos remanescentes florestais. Neste trabalho nós mostramos que em um fragmento florestal dominado por bambu (Guadua weberbaueri Pilger) no sudoeste da Amazônia, o efeito de borda deve ser confundido pelo efeito efeito do bambu, que também ocorre no interior da floresta. Nós medimos as taxas de incremento diamétrico, mortalidade e recrutamento de árvores com DAP (diâmetro a altura do peito) $\geq 10 \mathrm{~cm}$, em um fragmento dominado por floresta aberta com bambu no sudoeste da Amazônia, estado do Acre, Brasil, em 15 parcelas na borda da floresta e 15 a $500 \mathrm{~m}$ da borda no interior do fragmento florestal. O intervalo de tempo entre os censos foi de 1,8 anos. A taxa anual de incremento diamétrico médio diferiu significativamente entre borda $\left(3,82 \pm 0,10 \mathrm{~mm} \mathrm{a}^{-1}\right)$ e interior $\left(2,39 \pm 0,18 \mathrm{~mm} \mathrm{a}^{-1}\right)$; mas não houve diferenças na taxa anual de mortalidade (borda $=3.8 \pm 2.5 \% \mathrm{a}^{-1} \mathrm{CV}=65.7 \%$; interior $=3.6 \pm 2.6 \% \mathrm{a}^{-1} \mathrm{CV}=72.2 \%$ ) e na taxa anual de recrutamento (borda $=7.1 \pm 3.2 \% \mathrm{a}^{-1} \mathrm{CV}=45 \%$; interior $=8.9 \pm 7.9 \% \mathrm{a}^{-1} \mathrm{CV}=88.7 \%$ ). A taxa de incremento diamétrico, especialmente de espécies arbóreas de estágios iniciais de sucessão ecológica e crescimento rápido, é favorecida pelas condições ambientais da borda, onde a abundância de bambu é maior. Porém, a ausência de efeito de borda sobre a mortalidade e recrutamento, pode ser devido a própria dinâmica das manchas de bambu, que podem estar imitando as bordas das florestas, e portanto, mascarando o efeito de borda neste fragmento. Nós especulamos que os padrões de mortalidade e recrutamento em florestas fragmentadas no Sudoeste da Amazônia são diferentes de outras partes da bacia Amazônica e que o bambu nessas florestas é um dos principais atores controlando a sucessão florestal nesses fragmentos.

Palavras-chave: fragmentação florestal, efeito de borda, floresta aberta com bambu, comunidade vegetal, sucessão florestal, dinâmica de florestas tropicais. 


\section{Introduction}

Because of the key role of the Amazon in maintaining the global climate and biodiversity (Malhi et al. 2008, Salati \& Vose 1984, Phillips et al. 1998, Fearnside 1999, Laurance et al. 2010), it becomes more and more important to understand edge effects on plant communities and ecosystem processes, as a result of landscape fragmentation caused mainly by the expansion of agriculture, cattle ranching (Barona et al. 2010), construction and by building the infrastructure need for the production and distribution of products associated with development projects (Soares-Filho et al. 2006). Between 2001 and 2010, the Brazilian Amazon lost an average of $16.153 \pm 7.500 \mathrm{~km}^{2} /$ year of mature forest (Instituto... 2010), which is the equivalent of $10 \%$ of Acre State total area. As a direct consequence, the remaining forests have been gradually fragmented and isolated within a matrix dominated by pasture, annual monocultures or secondary forest patches at different successional stages.

In addition to habitat loss and changes in biological populations, changes in land cover decrease the effectively preserved area, due to edge effects (Nascimento \& Laurance 2006), which include modifications in physical, chemical and biological parameters caused by the contact between the fragment and the matrix (Wiens et al. 1993, Murcia 1995, Primak \& Rodrigues 2001). Fragment edges are strongly affected by external disturbances in many important ecosystem processes (Laurance et al. 2002), such as total photosynthetic rate (MacDougall \& Kellman 1992), density of individuals, primary productivity and floristic diversity (Didhan \& Lawton 1999).

In the Central Amazon, Laurance \& Yensen (1991), Laurance et al. (1998a, b, 2000), Murcia (1995) and (Kapos 1989) observed that the edge effect changes species composition and affects diameter growth, mortality and recruitment, due to several factors, such as the reduction of water supply in the soil, increase in light penetration in the border, even after decades of the fragmentation processes (Oliveira Filho et al. 1997).

Southwestern Amazon has also undergone a process of fragmentation and vegetation loss, especially due to the expansion of cattle raising, agriculture, logging (Baitz et al. 2008) and road paving (Brown et al. 2002). Nevertheless, western Amazonia is known for the extensive cover $\left(165,000 \mathrm{~km}^{2}\right)$ of open forests dominated by bamboos of the genus Guadua (Smith \& Nelson 2011). These bamboos strongly affect the structure and dynamics of these forests, causing a decrease in tree density, total basal area, floristic richness and in functional groups (Oliveira 2000, Smith 2000, Silveira 2005, Griscom \& Ashton 2003, Griscom et al. 2007).

We speculate that where forests are dominated by bamboo, forest dynamics might be different, since bamboo does influence forest structure elsewhere in western Amazonia (Griscom \& Ashton 2003). Due to a lack of knowledge of the impact of forest fragmentation on edge effects in southwestern Amazonia, we measured tree growth, mortality rate and recruitment on the edge and in the interior of a bamboo dominated forest fragment to address this hypothesis.

\section{Material and Methods}

\section{Study area}

Catuaba Experimental Farm possesses a forest fragment with ca. 1,200 ha located in Senador Guiomard, state of Acre $\left(10^{\circ} 04^{\prime} \mathrm{S}\right.$ and $\left.67^{\circ} 37^{\prime} \mathrm{W}\right)$. It has a gently rolling topography with predominance of oxisols and to a lesser extent ultisols (Acre 2006); the A and B horizons are predominantly formed by sand (62 and $47 \%$, respectively) and the $\mathrm{pH}$ is approximately 4.0 (Sousa et al. 2008). The fragment is at an average altitude of $214 \mathrm{~m}$ a.s.1. and is $0.8-7.4 \mathrm{~km}$ away from neighboring remnants. The area is covered by bamboo dominated open rainforest, in which understory vines and culms of Guadua weberbaueri Pilger are very abundant. The dominant trees are Hevea brasiliensis (Willd. ex A. Juss.) Müll.Arg. (Euphorbiaceae), Bertholletia excelsa Humb. \& Bonpl. (Lecythidaceae), Tetragastris altissima (Aubl.) Swart (Burseraceae) and Carapa guianensis Aubl. (Meliaceae). Canopy height is between 20 and $40 \mathrm{~m}$, with emergent trees up to $45 \mathrm{~m}$ (Silveira 2005). Mean annual rainfall is $1,958 \mathrm{~mm}$, varying from $846 \mathrm{~mm}$ in the wettest quarter (January to March) to $197 \mathrm{~mm}$ in the driest quarter (July to September). The average annual temperature is $25.3{ }^{\circ} \mathrm{C}$, ranging from 17 to $32.7^{\circ} \mathrm{C}$ (Duarte 2006).

\section{Tree community sampling}

We randomly selected three areas, and in each area two $500 \times 10$ $\mathrm{m}$ transects were set parallel to $500 \mathrm{~m}$ apart from each other: one at the edge, $10 \mathrm{~m}$ from the non-forested matrix, and one inside the forest, $500 \mathrm{~m}$ from the first area. On each transect five $100 \times 10 \mathrm{~m}$ plots were delimited, where all live trees, as well as lianas and palms, were permanently marked with aluminum tags at $1.60 \mathrm{~m}$ and referenced by $\mathrm{x} / \mathrm{y}$ coordinates. All individuals $(\mathrm{DBH} \geq 10 \mathrm{~cm}$ ) had their diameter measured at $1.3 \mathrm{~m}$; buttressed trees were measured $50 \mathrm{~cm}$ above the end of the roots according RAINFOR field protocols. The RAINFOR field protocols are available at http://www.geog.leeds.ac.uk/ projects/ rainfor/rainforfield manual.doc.

The first census was carried out between October and November 2007, and a second census was carried out in September 2009; all individuals were checked for DBH on both occasions. Dead individuals were counted, and individuals that met the minimal criterion of inclusion 1.8 years after the first measurement were marked as recruits and measured.

The annual diameter growth for each individual was calculated using the formula $\left(\mathrm{DBH}_{1}-\mathrm{DBH}_{0}\right) / \mathrm{t}$, where $\mathrm{DBH}_{0}$ represents the initial diameter, $\mathrm{DBH}_{1}$ represents the diameter measured in the second census, and $t$ represents the time interval between measurements. There were 191 individuals excluded ( $15 \%$ of total) from our analyses, due to very high buttresses or other bark characteristics which caused measuring errors $(n=58$ border; $n=53$ interior, not statistically different) and others because they were dead ( $\mathrm{n}=48$ border; 32 interior, not statistically different). Since the differences in excluded trees were not significantly different, such exclusion was probably not a bias in our results.

Mortality (M) and Recruitment (R) rates were calculated following Sheil \& May (1996), using the formulas below, where $N_{0}$ is the initial number of individuals, $m$ is the number of dead individuals, $r$ is the number of recruits, and $t$ the elapsed time between censuses (Equations 1 and 2):

$$
\begin{aligned}
& M=\left\{1-\left[\left(\mathrm{N}_{0}-\mathrm{m}\right) / \mathrm{N}_{0}\right]^{1 / t}\right\} \times 100 \\
& \mathrm{R}=\left\{\left[\left(\mathrm{N}_{0}+\mathrm{r}\right) / \mathrm{N}_{0}\right]^{1 / \mathrm{t}}-1\right\} \times 100
\end{aligned}
$$

To test the influence of size on diameter growth and mortality, individuals were categorized in three DBH classes: $10-30 \mathrm{~cm}, 30.1$ $50 \mathrm{~cm}$ and over $50 \mathrm{~cm}$. Data was normal and homocedastic and we used a one-way ANOVA to test differences among diameter classes.

\section{Results}

\section{Diameter growth rate}

Out of the 1,291 individuals sampled, the total number recorded in the edge (498.6 ind./ha) differed significantly (ANOVA: $\mathrm{F}=7.7$ $\mathrm{p}=0.022)$ from the interior $\left(362 \mathrm{ind} . \mathrm{ha}^{-1}\right)$. The average annual growth 
rate at the edge $\left(3.82 \pm 0.10 \mathrm{~mm} \cdot \mathrm{a}^{-1}\right)$ was significantly $(\mathrm{p}<0.001)$ higher than in the interior $\left(2.39 \pm 0.18 \mathrm{~mm} \mathrm{a}^{-1}\right)$, Table 1 .

Diameter growth at $10-30 \mathrm{~cm} \mathrm{DBH}$ at the edge was significantly (ANOVA: $F=3.8 p=0.05$ ) higher than the forest interior. However, the difference was not significant for trees with $\mathrm{DBH}$ 30-50 cm (ANOVA: $F=0.03 \mathrm{p}=0.86$ ) and $\mathrm{DBH}>50 \mathrm{~cm}$ (ANOVA: $F=0.35 p=0.55$ ). Such positive relationship between $\mathrm{DBH}$ and growth rate was also observed separately in the edge $\left(10-30 \mathrm{~cm}=3.63 \pm 2.07 \mathrm{~mm} \mathrm{a}^{-1} ; 30.1-50 \mathrm{~cm}=4.6 \pm 4.0 \mathrm{~mm} \mathrm{a}^{-1}\right.$; and $>50 \mathrm{~cm}=7.52 \pm 12.44 \mathrm{~mm} \mathrm{a}^{-1}$ ) and in the interior $\left(10-30 \mathrm{~cm}=2.34 \pm 1.47 \mathrm{~mm} \mathrm{a}^{-1} ; 30.1-50 \mathrm{~cm}=3.29 \pm 3.08 \mathrm{~mm} \mathrm{a}^{-1}\right.$; and $\left.>50 \mathrm{~cm}=6.28 \pm 8.08 \mathrm{~mm} \mathrm{a}^{-1}\right)$.

\section{Mortality and Recruiting rates}

Total mortality rate was $3.77 \pm 2.55 \% \mathrm{a}^{-1}$. The number of individuals in each census and their respective mortality rates are presented in Table 1. Annual mortality rate was not difference between edge $\left(3.89 \pm 2.58 \% \mathrm{a}^{-1}\right)$ and interior forest $(3.65 \pm 2.60 \%$ $\mathrm{a}^{-1}$ ). Total average mortality rate (edge plus interior) for plants with DBH $10-30 \mathrm{~cm}\left(4.13 \pm 3.20 \% \mathrm{a}^{-1}\right)$ was significantly higher $(\mathrm{p}=0.002$, Mann-Whitney U Test) than in the class $30.1-50 \mathrm{~cm}(3.45 \pm 6.38 \%$ $\left.\mathrm{a}^{-1}\right)$. In the edge this rate differed significantly $(\mathrm{p}=0.015 \mathrm{Mann}-$ Whitney U test) between the classes of DBH 10-30 (4.09\% $\left.\mathrm{a}^{-1}\right)$ and $30.1-50 \mathrm{~cm}\left(3.41 \% \mathrm{a}^{-1}\right)$. In the interior, although the mortality rate was higher in the class $10-30\left(4.17 \% \mathrm{a}^{-1}\right)$ than in the class $30.1-50$ $\left(3.48 \% \mathrm{a}^{-1}\right)$, the difference was not significant. There was also no significant difference between edge and interior for the DBH classes of $10-30 \mathrm{~cm}(\mathrm{p}=0.945)$ and $30.1-50 \mathrm{~cm}(\mathrm{p}=0.966)$.

Although between 2007 and 2009 no mortality of individuals with DBH over $50 \mathrm{~cm}$ was recorded, 80 individuals died in the other two classes, and 176 individuals were included in the second census as recruits, which resulted in a recruitment rate of $7.22 \% \mathrm{a}^{-1}$ (Table 1). In the edge, the recruitment rate was $7,16 \pm 3,29 \% \mathrm{a}^{-1}$, and in the interior it was $8,98 \pm 7,96 \% \mathrm{a}^{-1}$; nevertheless this difference was not significant $(\mathrm{p}=0.397)$.

\section{Discussion}

\section{Diameter growth}

The average diameter growth rate observed in the present study $\left(3.10 \mathrm{~mm} \mathrm{a}^{-1}\right)$ is similar to the rates reported by Selhorst (2005) (3.6 $\left.\mathrm{mm} \mathrm{a}^{-1}\right)$ and Vieira (2003) $\left(3.9 \mathrm{~mm} \mathrm{a}^{-1}\right)$, in a assessments of the same area four and two years respectively. Despite the small variation, these rates are higher than the rates measured in others dense forests of Amazon basin $\left(1.8 \mathrm{~mm} \mathrm{a}^{-1}\right.$ by Silva et al. 2002, $1.6 \mathrm{~mm} \mathrm{a}^{-1}$ by Higuchi et al. 2003, $2.0 \mathrm{~mm} \mathrm{a}^{-1}$ by Carvalho et al. 2004, and $1.4 \mathrm{~mm}$ $\mathrm{a}^{-1}$ by Laurance et al. 2004). Thus, trees in southwestern Amazonia grow up to twice as fast as the ones in Oriental Amazon, which could result from variations in chemical and physical properties of the soil (Malhi et al. 2004, Quesada et al. 2009 \& Quesada et al. 2010) and also by the dominant functional group - fast growing light-weighted species.

The significant difference in diameter growth rate between edge and interior probably occurs due to changes in microclimatic conditions (Camargo \& Kapos 1995, Kapos et al. 1997, Laurance et al. 1998a, 2001), which are more favorable in the edge to the establishment of pioneer species, which grow faster and have a shorter life cycle (Lieberman \& Lieberman 1987). Furthermore, bamboos are known to influence the structure of the forest (Silveira 2005, Oliveira 2000, Griscom \& Ashton 2003, 2006). Griscom \& Ashton (2006), showed that the bamboo control succession forest and thus can act as a filter, particularly for some species characteristic of early stages succession, which in general tend to exhibit rapid growth (Silveira 2005, Oliveira 2000, Griscom et al. 2007). In addition, bamboo density at the edge $\left(3394 \pm 1121\right.$ culms ha $\left.^{-1}\right)$ is two times higher than in the interior forest $\left(1269 \pm 824.49\right.$ culms ha $\left.^{-1}\right)$ (Castro et al. 2013). Thus, even without concrete evidence, we believe that the higher growth rate at the edge could be influenced by a combination of edge plus bamboo effects; which is not reported in the literature so far.

\section{Mortality and tree recruitment}

Not only the total mortality rates $\left(3.77 \% \mathrm{a}^{-1}\right)$ is more than three times higher than the rates observed in Central Amazon by Higuchi et al. (1997; 1.03\%), Rocha (2001; 0.86\%), and Teixeira et al. $(2007 ; 1.13 \%)$, but also no edge effect was detected for this process. In Central Amazon, mortality rate is higher in the edge, and is related mainly to a combination of microclimatic conditions, wind turbulence and liana loads (Ferreira \& Laurance 1997, Laurance et al. 1998a, 2000, Nascimento \& Laurance 2006). Tree mortality is also higher for larger individuals (Hubell \& Foster 1990, Laurance et al. 1998a, 2000).

In present study, in addition to the combination of those factors, the disturbance caused by bamboos (Silveira 2005, Griscom \& Ashton, 2003) should also be considered. Tree mortality could be related more to bamboo density than to the edge effect. We suggest that the higher mortality in forests with bamboos, mainly in smaller size classes, is related to the disturbance regime imposed by G. weberbaueri (Silveira 2005, Griscom \& Ashton 2006), favoring the establishment and growth of pioneer species that, due to their shorter life cycle, contribute more to the increase in mortality rate than the species that are characteristic of later successional stages (Silveira 1999, Swaine \& Whitmore 1988). And since there is a greater bamboo abundance in edge plots, this may be the cause for our results.

Contrary to what was observed by Laurance et al. (1998a, b, 2001) and Bierregaard et al. (2001), the recruitment rate in the present study did not differ significantly between edge and interior. Again, this similarity between edge and interior might be attributed to

Table 1. Tree mortality, recruitment and diameter growth in a forest fragment in southwestern Amazon, state of Acre, Brazil. $\mathrm{N}_{0}$ : number of individuals in 2007 and $\mathrm{N}_{1}$ : number of individuals in 2009

\begin{tabular}{lccc}
\hline \multicolumn{1}{c}{ Variables } & Edge & Interior & General \\
\hline $\mathrm{N}_{\mathbf{0}}\left(\right.$ ind ha $\left.^{-1}\right)$ & 498,6 & 362 & 430,3 \\
$\mathrm{~N}_{\mathbf{1}}\left(\right.$ ind ha $\left.^{-1}\right)$ & 529,3 & 395,3 & 462,3 \\
Survivors & 701 & 510 & 1211 \\
Dead & 48 & 32 & 80 \\
Recruits & 93 & 81 & 174 \\
Diameter growth $\left(\mathrm{mm} \mathrm{a}^{-1}\right)$ & $3,82 \pm 0,10$ & $2,39 \pm 0,18$ & $3,10 \pm 0,98$ \\
Annual mortality rate $\left(\% \mathrm{a}^{-1}\right)$ & $3,89 \pm 2,58$ & $3,65 \pm 2,60$ & $3,77 \pm 2,55$ \\
Annual recruitment rate $\left(\% \mathrm{a}^{-1}\right)$ & $7,16 \pm 3,29$ & $8,98 \pm 7,96$ & $8,10 \pm 6,09$ \\
\hline
\end{tabular}


bamboo dominance, which occurs in both areas. Griscom \& Ashton (2006), in an experiment with 'artificial trees', showed that in plots dominated by bamboos ( $G$. sarcocarpa Londoño \& P.M.Peterson and G. weberbaueri), the frequency of damage and weight load can be up to eight times higher than in plots without bamboos. Despite the lack of difference between interior and edge, the average recruitment rate was $40 \%$ higher than the mortality rate. This can be related to the open architecture of the canopy, which favors the recruitment of early successional plant species, such as pioneers and small gap specialists, which are tolerant to microclimatic conditions of open environments (Williams-Linera 1990, Laurance et al. 1998b).

Recruitment rate among interior forest plots varies widely $(\mathrm{CV}=88 \%)$ and we think that bamboo can be favoring the recruitment of some species characteristic of early successional stages (Silveira 2005, Griscom \& Ashton 2003, 2006, Griscom et al. 2007). Although the results shown here are not very robust in terms of replication, and that mortality and recruitment did not show the same trend as growth, bamboo is likely to be selecting pioneer and small gap specialists (sensu Denslow 1980) such as Acacia polyphyla DC. and Castila ulei Warb., which regenerate and re-sprout within bamboo patches (Griscom \& Ashton 2006, Silveira 2005).

Thus, we suggest that in fragments dominated by bamboo, the edge effect may not the single major factor responsible for tree mortality and recruitment and bamboos might be masking some probable but not detectable edge effect on tree mortality and recruitment. Such results show that the area studied is still in a process of re-establishment and regeneration after the last synchronous mortality of bamboos (approximately 30 years ago). In addition, we speculate that bamboo patches of different ages might impose different effects on forest dynamics in southwestern Amazonia. Therefore, further and longer studies are important to address the influence of bamboo and edge at the same time and therefore corroborate or refute our preliminary results.

\section{Acknowledgements}

Conselho Nacional de Desenvolvimento Científico e Tecnológico for funding the project 'Efeitos de borda sobre um remanescente florestal na Amazônia sul-ocidental: Acre-Casadinho (620236/2006-0)' and for granting a scholarship to Herison Medeiros and Wendeson Castro (PIBIC/CNPq); Large Scale BiosphereAtmosphere Experiment in Amazonia (LBA); Superintendência da Zona Franca de Manaus (Convênio:100/07 Suframa-UFAC) and the team of the Laboratory of Botany and Plant Ecology, in particular, Edilson Consuelo, Flávio Obermuller and Lívia Souza who helped us with field work. We also thank Bruce Nelson for comments and discussion on bamboo patches of different sizes.

\section{References}

ACRE. Governo do Estado. 2006. Zoneamento ecológico-econômico do Acre fase II. SEMA, Rio Branco, 356p.

BAITZ, W., PEREIRA, D. \& LENTINI, M. 2008. O setor madeireiro da Amazônia brasileira. In $\mathrm{O}$ manejo da paisagem e a paisagem do manejo (N. Bensusan \& G. Armstrong, coords.). Instituto Internacional de Educação do Brasil, Brasília, 312p.

BARONA, E., KUTTY, N.R., HYMAN, G. \& COOMES, O.T. 2010. The role of pasture and soybean in deforestation of the Brazilian Amazon. Environ. Res. Lett. 5:024002. http://dx.doi.org/10.1088/1748-9326/5/2/024002

BIERREGAARD, R.O., GASCON, C., LOVEJOY, T.E. \& MESQUITA, R. 2001. Lessons from Amazonia: ecology and conservation of a fragmented forest. Yale University Press, London.
BROWN, I.F., BRILHANTE, S., MENDOZA, E. \& OLIVEIRA, I. 2002. The highway from Rio Branco, Acre, Brazil to Pacific ports: How to maximize the benefits and minimize the adverse impacts for sustainable development of southwestern Amazonia. Encuentro Internacional de Integración Regional - Bolívia, Brasil y Perú. Arequipa, Peru, 2 a 4 de setembro de 2001. Editora CEPEI (Centro Peruano de Estudios Internacionales), Lima.

CAMARGO, J.L.C. \& KAPOS, V. 1995. Complex edges effects on soil moisture and microclimate in Central Amazonian Forest. J. Trop. Ecol. 11:205-221. http://dx.doi.org/10.1017/S026646740000866X

CARVALHO, J.O.P., SILVA, J.N.M. \& LOPES, J.C.A. 2004. Growth rate of terra firm rain forest in Brazilian Amazonia over an eight-year period in response to logging. Acta Amazon. 34(2):209-217. http://dx.doi. org/10.1590/S0044-59672004000200009

DENSLOW, J.S. 1980. Gap partitioning among tropical rainforest trees. Biotropica 12:47-51. http://dx.doi.org/10.2307/2388156

DIDHAN, R.K. \& LAWTON, J.H. 1999. Edge structure determines the magnitude of changes in microclimate and vegetation structure in tropical forest fragments. Biotropica 31:17-30.

DUARTE, A.F. 2006. Aspectos da climatologia do Acre, Brasil, com base no intervalo 1971-2000. Rev. Bras. Meteorol. 21(3b):308-317.

FEARNSIDE, P.M. 1999. Biodiversity as an environmental service in Brazil's Amazonian forests: risks, value and conservation. Environ. Conserv. 26:305-321. http://dx.doi.org/10.1017/S0376892999000429

FERREIRA, L.V. \& LAURANCE, W.F. 1997. Effects of Forest Fragmentation on Mortality and Damage of Selected Trees in Central Amazonia. Conserv. Biol. 11(3):797-801. http://dx.doi.org/10.1046/j.1523-1739.1997.96167.x

GRISCOM, B.W. \& ASTHTON, P.M.S. 2003. Bamboo control of forest succession: Guadua sarcocarpa in southeastern Peru. For. Ecol. Manage. 175:445-454. http://dx.doi.org/10.1016/S0378-1127(02)00214-1

GRISCOM, B.W. \& ASHTON, P.M.S. 2006. A self-perpetuating bamboo disturbance cycle in a Neotropical forest. J. Trop. Ecol. 22:587-597. http://dx.doi.org/10.1017/S0266467406003361

GRISCOM, B.W., DALY, D.C. \& ASTHTON, P.M. 2007. Floristics of bamboo-dominated stands in lowland terra-firma forests of southwestern Amazonia. J. Torrey Bot. Soc. 134(1):108-125. http://dx.doi. org/10.3159/1095-5674(2007)134[108:FOBSIL]2.0.CO;2

HIGUCHI, N., SANTOS, J., RIBEIRO, R.J., FREITAS, J.V., VIEIRA, G., CÖIC, A. \& MINETTE, L.J. 1997. Crescimento e Incremento de uma Floresta Amazônica de Terra-Firme Manejada Experimentalmente. In Relatório Final do Projeto bionte. Biomassa e Nutrientes Florestais - MCT/ INPA. Manaus, p. 89-131.

HIGUCHI, N., CHAMBERS, J.Q., SILVA, R.P., MIRANDA, E.V., SANTOS, J., LIDA, S., PINTO, A.C.M., ROCHA, R.M. \& SOUZA, C.A.S 2003. Uso de bandas metálicas e dendrômetros automáticos para a definição do padrão de crescimento individual das principais espécies arbóreas da floresta primária da região de Manaus, Amazonas, Brasil. In Projeto Jacarnada Fase II: Pesquisas Florestais na Amazônia Central. p. 55-68.

HUBELL, S.P. \& FOSTER, R.B. 1990. Structure, dynamics and equilibrium status of old-growth forest on Barro Colorado Island. In GENTRY, A.H., ed. Four neotropical rainforests. Yale University Press, New Haven, p.522-541.

HUBBELL, S.P., FOSTER, R.B., O'BRIEN, S.T., HARMS, K.E., CONDIT, R., WECHSLER, B., WRIGHT, S.J. \& LOO DE LAO, S. 1999. Light gap-disturbances, recruitment limitation, and tree diversity in a neotropical forest. Science 283:554-557. http://dx.doi.org/10.1126/ science.283.5401.554

INSTITUTO NACIONAL DE PESQUISAS ESPACIAIS - INPE. 2010. Projeto Prodes Monitoramento da Floresta Amazônica Brasileira por Satélite. http://www.obt.inpe.br/prodes/index.html (último acesso em 15/02/2010).

KAPOS, V. 1989. Effects of isolation on the water status of forest patches in the Brazilian Amazon. J. Trop. Ecol. 5:173-185. http://dx.doi.org/10.1017/ S0266467400003448 
KAPOS, V., CAMARGOS, J.L.C. \& DANDE, G. 1997. Edge related changes in environment and plant response due to forest fragmentation in Central Amazonia. In Tropical forest remnants: ecology, management and conservation of fragmented communities (W.F. Laurance \& R.O. Bierregaard, eds.). University of Chicago Press, Chicago, p.45-54.

LAURANCE, W.F. \& YENSEN, E. 1991. Predisting the impacts of edge effects in fragmented habitats. Biol. Conserv. 55:77-92. http://dx.doi org/10.1016/0006-3207(91)90006-U

LAURANCE, W.F., FERREIRA, L.V., RANKIN-DE-MERONA, J.M. \& LAURANCE, S. G. 1998a. Rain forest fragmentation and the dynamics of Amazonian tree communities. Ecology 79(6):2032-2040. http://dx.doi org/10.1890/0012-9658(1998)079[2032:RFFATD]2.0.CO;2

LAURANCE, W.F., FERREIRA, L.V., RANKIN-DE MERONA, J.M., LAURANCE, S.G., HUTCHINGS, R. \& LOVEJOY, T.E. 1998b. Effects of forest fragmentation on recruitment patterns in Amazonian tree communities. Conserv. Biol. 12(2):460-464. http://dx.doi.org/10.1046/ j.1523-1739.1998.97175.x

LAURANCE, W.F., DELAMÔNICA,P., LAURANCE, S.G., VASCONCELOS, H.L. \& LOVEJOY, T.L. 2000. Rainforest fragmentation kills big trees. Nature 404:20. http://dx.doi.org/10.1038/35009032

LAURANCE, W.F., PEREZ-SALICRUP, D., DELAMONICA, P., FEARNSIDE, P.M., D'ANGELO, S., JEROZOLINSKI, A., POHL, L. \& LOVEJOY, T.E. 2001. Rain forest fragmentation and the structure of Amazonian liana communities. Ecology 82:105-116. http://dx.doi. org/10.1890/0012-9658(2001)082[0105:RFFATS]2.0.CO;2

LAURANCE, W.F., LOVEJOY, T.E., VASCONCELOS, H.L., BRUNA, E.M, DIDHAM, R.F., STOUFFER, P.C., GASCON, C., BIERREGAARD, R.O., LAURANCE, S.G. \& SAMPAIO, E. 2002. Ecosystem decay of Amazonian forest fragments: a 22 -year investigation. Conserv. Biol. 16(3):605-618. http://dx.doi.org/10.1046/j.1523-1739.2002.01025.x

LAURANCE,W.F., NASCIMENTO, H.E.M., LAURANCE, S.G., CONDIT, R., D'ANGELO, S. \& ANDRADE, A. 2004. Inferred longevity of Amazonian rain forest trees based on along-term demographic study. For. Ecol. Manage. 190:131-143. http://dx.doi.org/10.1016/j. foreco.2003.09.011

LAURANCE, S.G.W., ANDRADE, A. \& LAURANCE, W.F. 2010 Unanticipated Effects of Stand Dynamism on Amazonian Tree Diversity. Biotropica 42(4):429-434. http://dx.doi.org/10.1111/j.17447429.2009.00611.x

LIEBERMAN, D. \& LIEBERMAN, M. 1987. Forest tree growth and dynamics et La Selva, Costa Rica (1969-1982). J. Trop. Ecol. 3:347-358. http://dx.doi.org/10.1017/S0266467400002327

MALHI, Y., BAKER, T.R., PHILLIPS, O.L., ALMEIDA, S., ALVAREZ, E., ARROYO, L., CHAVE, J., CZIMCZIK, C.I., DI FIORE, A., HIGUCHI, N., KILLEEN, T.J., LAURANCE, S.G., LAURANCE, W.F., LEWIS, S.L., MONTOYA, L.M.M., MONTEAGUDO, A., NEILL, D.A., VARGAS, P.N., PATIÑO, S., PITMAN, N.C.A., QUESADA, C.A., SALOMAO, R., SILVA, J.N.M., LEZAMA, A.T., MARTINEZ, R.V., TERBORGH, J., VINCETI, B. \& LLOYD, J. 2004. The above-ground coarse wood productivity of 104 Neotropical forest plots. Glob. Chang. Biol. 10:563-591. http://dx.doi.org/10.1111/j.1529-8817.2003.00778.x

MALHI Y., ROBERTS, J.T., BETTS, R., KILLEEN T.J., LI, W. \& NOBRE, C.A. 2008. Climate change, deforestation, and the fate of the Amazon. Science 319:169-172. http://dx.doi.org/10.1126/science.1146961

MacDOUGALL, A. \& KELLMAN, M. 1992. The understorey light regime and patterns of tree seedlings in tropical riparian forest patches. J. Biogeogr. 19:667-675. http://dx.doi.org/10.2307/2845708

MURCIA, C. 1995. Edge effects in fragmented forests: implications for conservation. Trends Ecol. Evol. 10:58-62. http://dx.doi.org/10.1016/ S0169-5347(00)88977-6

NASCIMENTO, H.E.M. \& LAURANCE, W.F. 2006. Efeitos de área e de borda sobre a estrutura florestal em fragmentos de floresta de terra-firme após 13-17 anos de isolamento. Acta Amazon. 36(2):183-192. http:// dx.doi.org/10.1590/S0044-59672006000200008
OLIVEIRA, A. C. A. 2000. Efeitos do bambu Guadua weberbaueri Pilger sobre a fisionomia e estrutura de uma floresta no sudoeste da Amazônia. Dissertação de mestrado, Instituto Nacional de Pesquisa na Amazônia, Universidade do Amazonas, Manaus.

OLIVEIRA FILHO, A.T., MELLO, J.M. \& SCOLFORO, J.R.S. 1997. Effects of past disturbance and edges on tree community structure and dynamics within a fragment of tropical semideciduous forest in south-eastern Brazil over a five year period (1987-1992). Plant Ecol. 131:45-66. http://dx.doi. org/10.1023/A:1009744207641

PHILLIPS, O.L., MALHI, Y., HIGUCHI, N., LAURANCE, W.F., NUNEZ, P., VASQUEZ, R., LAURANCE, S.G., FERREIRA, L., STERN, M., BROWN, S. \& GRACE, J. 1998. Changes in the carbon balance of tropical forests: evidence from long-term plots. Science 282:439-442. http://dx.doi.org/10.1126/science.282.5388.439

PRIMAK, R.B. \& RODRIGUES, E. 2001. Biologia da Conservação. Londrina, Midiograf.

QUESADA, C.A., LLOYD, J., SCHWARZ, M., BAKER, T.R., PHILLIPS, O.L., PATIÑO, S., CZIMCZIK, C., HODNETT, M.G., HERRERA, R., ARNETH, A., LLOYD, G., MALHI, Y., DEZZEO, N., LUIZÃO, F.J., SANTOS, A.J.B., SCHMERLER, J., ARROYO, L., SILVEIRA, M., PRIANTE FILHO, N., JIMENEZ, E.M., PAIVA, R., VIEIRA, I., NEILL, D.A., SILVA, N., PEÑUELA, M.C., MONTEAGUDO, A., VÁSQUEZ, R., PRIETO, A., RUDAS, A., ALMEIDA, S., HIGUCHI, N., LEZAMA, A.T., LÓPEZ-GONZÁLEZ, G., PEACOCK, J., FYLLAS, N.M., ALVAREZ DÁVILA, E., ERWIN, T., DI FIORE, A., CHAO, K.J., HONORIO, E., KILLEEN, T., PEÑA CRUZ, A., PITMAN, N., NÚÑEZ VARGAS, P., SALOMÃO, R., TERBORGH, J. \& RAMÍREZ, H. 2009. Regional and large-scale patterns in Amazon Forest structure and function are mediated by variations in soil physical and chemical properties Biogeosciences 6:3993-4057. http://dx.doi.org/10.5194/bgd-6-3993-2009

QUESADA, C.A., LLOYD, J., SCHWARZ, M., PATIÑO, S., BAKER, T.R., CZIMCZIK, C., FYLLAS, N.M., MARTINELLI, L. NARDOTO, G. B., SCHMERLER, J., SANTOS, A.J.B., HODNETT, M.G., HERRERA, R., LUIZÃO, F.J., ARNETH, A., LLOYD, G., DEZZEO, N., HILKE, I., KUHLMANN, I., RAESSLER, M., BRAND, W.A., GEILMANN, H., MORAES FILHO, J.O., CARVALHO, F.P., ARAUJO FILHO, R.N., CHAVES, J.E., CRUZ JUNIOR, O.F., PIMENTEL, T.P. \& PAIVA, R. 2010. Variations in chemical and physical properties of Amazon forest soils in relation to their genesis. Biogeosciences 7:1515-1541. http:// dx.doi.org/10.5194/bg-7-1515-2010

ROCHA, R.M. 2001. Taxas de Recrutamento e Mortalidade da Floresta de Terra Firme da Bacia do Rio Cuieiras na Região de Manaus-AM. Dissertação de Mestrado, Instituto Nacional de Pesquisas da Amazônia, Universidade Federal do Amazonas, Manaus, Amazonas, 49p.

SALATI, E. \& VOSE, P.B. 1984. Amazon basin: a system in equilibrium. Science 225:129-138. http://dx.doi.org/10.1126/science.225.4658.129

SELHORST, D. 2005. Distribuição etária e incremento diamétrico arbóreo no Sudoeste da Amazônia: subsídios para o manejo florestal. Dissertação de mestrado, Universidade Federal do Acre, Rio Branco.

SILVA, R.P., SANTOS, J. TRIBUZY, E.S., CHAMBERS, J.Q., NAKAMURA, S. \& HIGUCHI, N. 2002. Diameter increment and growth patterns for individual tree growing in Central Amazon, Brazil. For. Ecol. Manage. 166:295-301. http://dx.doi.org/10.1016/S0378-1127(01)00678-8

SHEIL, D. \& MAY, R.M. 1996. Mortality and recruitment rate evaluations in heterogeneous tropical forests. J. Ecol. 84:91-100. http://dx.doi. org/10.2307/2261703

SILVEIRA, M. 1999. Ecological aspects of bamboo-dominated forest in southwestern Amazonia: an ethnoscience perspective. Ecotropica 5:213 216.

SILVEIRA, M. 2005. A floresta aberta com bambu no sudoeste da Amazônia. Padrões e processos em múltiplas escalas. ADUFAC, Rio Branco.

SMITH, M. 2000. Efeito de perturbações sobre a abundância, biomassa e arquitetura de Guadua weberbaueri Pilg. (Poaceae - Bambusoideae) em uma floresta dominada por bambu no Sudoeste da Amazônia. Dissertação de mestrado, Instituto Nacional de Pesquisa na Amazônia, Universidade do Amazonas, Manaus. 
Medeiros, H. et al.

SMITH, M. \& NELSON, B.W. 2011. Fire favours expansion of bamboodominated forests in the south-west Amazon. J. Trop. Ecol. 27:59-64. http://dx.doi.org/10.1017/S026646741000057X

SOARES-FILHO, B.S., NEPSTAD, D.C., CURRAN, L.M., CERQUEIRA, G.C., GARCIA, R.A., RAMOS, C.A., VOLL, E., McDONALD, A., LEFEBVRE, P. \& SCHLESINGER, P. 2006. Modelling conservation in the Amazon basin. Nature 430:520-523. http://dx.doi.org/10.1038/ nature 04389

SOUSA, E.S., SALIMON, C.I., VICTORIA, R.L., KRUSCHE, A.V., ALIN, S.R. \& LEITE, N.K. 2008. Dissolved inorganic carbon and $\mathrm{pCO}_{2}$ in two small streams draining different soil types in Southwestern Amazonia, Brazil. Rev. Ambi-Água 3(2):37-50. http://dx.doi.org/10.4136/ambiagua. 51

SWAINE, M.D. \& WHITMORE, T.C. 1988. On the definition of ecological species groups in tropical rain forests. Vegetatio 75:81-86. http://dx.doi. org/10.1007/BF00044629
TEIXEIRA, L.M., JEFFREY, Q., CHAMBERS, J.Q., SILVA, A.R., LIMA, A.J.N., CARNEIRO, V.M.C., SANTOS, J. \& HIGUCHI, N. 2007. Projeção da dinâmica da floresta natural de Terra-firme, região de Manaus-AM, com o uso da cadeia de transição probabilística de Markov. Acta Amazôn. 37(3):377-384. http://dx.doi.org/10.1590/S004459672007000300009

VIEIRA, S.A. 2003. Mudanças globais e taxas de crescimento arbóreo na Amazônia. Tese de Doutorado, Centro de Energia Nuclear na Agricultura, Universidade de São Paulo, Piracicaba.

WIENS, J.A., STENSETH, N.C., VAN HORNE, B. \& IMS, R.A. 1993. Ecological mechanisms and landscape ecology. Oikos 66:369-380. http:// dx.doi.org/10.2307/3544931

WILLIAMS-LINERA, G. 1990. Vegetation structure and environmental conditions of forest edges in Panama. J. Ecol. 78:356-373. http://dx.doi. org/10.2307/2261117 